\title{
Revisit Multiple Intelligences with the Roles of Motivation, Strategy, and Anxiety in Foreign Language Learning-A Case Study in Taiwan
}

\author{
Yi-An Hou \\ St. Mary's Junior College of Medicine, Nursing and Management, Taiwan \\ Email: hyn@smc.edu.tw
}

How to cite this paper: Hou, Y.-A. (2017) Revisit Multiple Intelligences with the Roles of Motivation, Strategy, and Anxiety in Foreign Language Learning-A Case Study in Taiwan. Open Access Library Journal, 4: e4057.

https://doi.org/10.4236/oalib.1104057

Received: October 23, 2017

Accepted: November 14, 2017

Published: November 17, 2017

Copyright (c) 2017 by author and Open Access Library Inc.

This work is licensed under the Creative

Commons Attribution International

License (CC BY 4.0).

http://creativecommons.org/licenses/by/4.0/

\begin{abstract}
The study was conducted to revisit multiple intelligences with the roles of motivation, strategy, and anxiety in foreign language learning. Subjects were 260 Hospitality management major students in a private five-year junior college in north-eastern Taiwan, including 114 males and 146 females. They helped to fill out the 226-item questionnaires dealing with multiple intelligences [1] [2], motivation [3], strategy [4], and anxiety [5]. The results revealed that a correlation among multiple intelligences, motivation, strategy, and anxiety did exist, and led to different English levels. Discussions, implications, and suggestions for students, teachers, parents, and schools were provided.
\end{abstract}

\section{Subject Areas}

Education

\section{Keywords}

Multiple Intelligences, Motivation, Strategy, Anxiety

\section{Introduction}

\subsection{Background of the Study}

Foreign languages, one of the three "substantive" courses in the Post-Sputnik Education Reform Movement (1957-1980), was not given as much attention as to that of science, technology, engineering, and mathematics (STEM) in the beginning (https://www.csun.edu/ vceed002/ref/curriculum/reforms/index.html), until 1959, when Gardner and Lambert introduced integrative-instrumental approach to measuring motivation, attention began to be shifted from the study of learners' behavior to the learning process of the language learners. It was this 
shift that gave definition to the field of second/foreign language learning. However, any research investigating second/foreign language learning can't avoid being dependent on the question: "Who learns what languages where" [6]. That is to say the learner, the target language, and the learning situation are the three major concerns of the study of second/foreign language. Particularly, there has been an increasing interest in changing the focus from the language learning product to the language learning processes, together with the fact that "the second half of the twentieth century can be called the age of individualism, when individual values and differences were recognized and respected" [7], consequently the factors dealing with language learners have attracted much more attention than ever before. Such factors include "unchangeable" ones (age, gender, aptitude, intelligence, and first language, etc.) and some other "predispositions" (motivation, attitude, tolerance of ambiguity, anxiety, field dependence/independence, cognitive styles, and learning strategies, etc.) [8]. Language learning is believed to be a complex process of input, processing, and output [9] and influenced by many "unchangeable" and "predispositions" factors. However, not much research has been conducted to explore some "unchangeable" factors, together with some other "predispositions" factors at the same time. Hence, the present study attempted to focus on an important "unchangeable" factor (multiple intelligences, MI) and some "predispositions", including motivation, strategy, and anxiety to revisit the theory of MI with the roles of motivation, strategy, and anxiety in a Taiwan setting where English is learned as a foreign language.

\subsection{Purpose of the Study}

The study aimed to revisit multiple intelligences with the roles of motivation, strategy, and anxiety about foreign language learning in a Taiwan setting, and provide some implications and suggestions for students, teachers, parents, and schools.

\subsection{Research Question}

The study was expected to provide answers to the main research question of how Taiwanese college students' multiple intelligences (MI) relate to motivation, strategy, and anxiety in their English learning.

\section{Related Literature}

The literature related studies about Multiple Intelligences (MI), motivation, strategy, and anxiety were described as follows:

\subsection{Multiple Intelligences}

According to Gardner [10], the father of the theory of Multiple Intelligence (MI), intelligence is "the ability to solve problems or fashion products that are valued in one or more cultural settings", and most of us have different combinations of intelligences. At first, Gardner had listed the seven intelligences which 
met his criteria for intelligences, namely, logical/mathematical intelligence, verbal/linguistic intelligence, visual/spatial intelligence, bodily/kinesthetic intelligence, musical/rhythmic intelligence, interpersonal intelligence, and intrapersonal intelligences; later, naturalist intelligence and existential intelligence were added [2] [11]. Since the MI theory was created, many bright, intelligent children have longer been limited by IQ tests, and logical/mathematical intelligence and verbal/linguistic intelligence have no longer been the traditional dominant factors to judge how smart the children are. Particularly, the MI theory helps educators be aware of working with such unique and diverse learners and need to expand their horizon of available teaching/learning tools [12] [13] [14]. Consequently, many studies related to MI have been blooming not only in America but also in many others; including Hou, et al. in Taiwan [14], Kim in Korea [15], Saeidi et al. in Iran [16], and dealing with different issues and consequences of "who, when, where, what, and how" [17].

It was described clearly how Gardner conceived these intelligences [2]:

1) Logical/Mathematical Intelligence-the ability to use numbers effectively and reason well. Sample skills are understanding the basic properties of numbers, the principles of cause and effect, and the ability to predict.

2) Verbal/Linguistic Intelligence-the ability to use words effectively, both orally and in writing. Sample skills are remembering information, convincing others to help, and talking about language itself.

3) Visual/Spatial Intelligence-the ability to sense form, space, color, line, and shape. Sample skills include the ability to represent visual or spatial ideas graphically.

4) Bodily/Kinesthetic Intelligence - the ability to use the body to express ideas and feelings, and to solve problems. Sample skills are coordination, flexibility, speed, and balance.

5) Musical/Rhythmic Intelligence-the ability to sense rhythm, pitch, and melody. Sample skills are recognizing simple songs and being able to vary speed, tempo, and rhythm in simple melodies.

6) Interpersonal Intelligence-the ability to understand another person's moods, feelings, motivations, and intentions. Sample skills are responding effectively to other people, problem solving, and resolving conflict.

7) Intrapersonal Intelligence - the ability to understand yourself, your strengths, weakness, moods, desires, and intentions. Sample skills are understanding how one is similar to or different from others, reminding oneself to do something, knowing about oneself as a language learner, and knowing how to handle ones' feelings.

8) Naturalist Intelligence-the ability to recognize species of plants or animals in one's environment.

9) Existential Intelligence-the ability to see the "big picture": "Why are we here?", "What is my role in the world?"

\subsection{Motivation and Attitude toward Foreign Language Learning}

Gardner and Lambert (1959) [18] divided motivation from a social psychological 
view into two categories: integrative and instrumental motivation. Instrumental motivation is viewed as the desire to learn a language in order to get a better job or meet a language requirement. By contrast, the integrative motivation is the desire to learn a language so as to integrate oneself into the target culture. Research findings have shown the relative importance of instrumental motivation and integrative motivation for language learning [3] [19] [20] [21]. In addition, motivation is considered one fundamental factor in language learning success because it helps determine the extent of involvement in learning [4] [18]. Dörnyei (1994) [6] claimed that without motivation, learners will not succeed in the long and tedious learning process no matter how splendid their language aptitude and intelligence level. In their study, furthermore, Oxford and Nyikon [22] stressed the fact that "The degree of expressed motivation to learn the language was the most powerful influence on strategy choice" (p. 294). Similar results were reported by Whartorn (2000) [23], who indicated that a significant relationship existed between the degree of motivation and the use of language learning strategies. As for attitude, Titone (1990) [9] indicated that attitudes "strictly tied up with motivational dynamics work most powerfully, especially in acquiring mastery in a second language. But attitudes may decline when classroom anxiety increases (Gardner and Lysynchuk, 1990) [24] and become less positive over time when appropriate feedback is not provided (Kraemer and Olshtain, 1989) [25]. Hence, it was suggested that "Developing sound attitudes is the first step toward the achievement of bilingualish" (Titone, 1990, p.1) [9].

\subsection{Foreign Language Learning Strategy Use}

In the last few decades, learning strategy has experienced tremendous growth, especially research on second foreign language learning strategies are "burgeoned" (Oxford and Cohen, 1992, p.2) [26]. According to Oxford, learning strategies are "specific actions taken by the learner to make learning easier, faster, more enjoyable, more self-directed, more effective, and more transferable to new situation" (Oxford, 1990, p.8) [4], which involve an interface of both "skill" and "will" (Paris, Lipson, and Wixson, 1983, cited in Yu, et al., 1995) [27]. Strategies are believed to be "malleable and teachable" (Oxford, 1990, p.440) [4]. Furthermore, much research on language learning strategies has established their role in language learning more efficient and effective and suggested that "strategy training in the language learning classroom can lead to a greater achievement” (Young, 1995, p.338) [28]. Hence, to improve language learning, the increasing interest of learning strategies has become one of the mainstreams since the 1990's. Oxford (1990) [4] divided strategies into six subcategories, including memory strategies, cognitive strategies, compensation strategies, metacognitive strategies, affective strategies, and social strategies, which are described as:

1) Memory Strategy-One of direct strategies that used to help learners remember and retrieve new knowledge.

2) Cognitive Strategy-One of direct strategies that used to help learners re- 
ceive, analyze, and produce information.

3) Compensation Strategy-One of direct strategies that used to help learners more comprehensive or productive despite knowledge gaps of language.

4) Metacognitive Strategy-One of indirect strategies that used to help learners coordinate their own learning processes.

5) Affective Strategy-One of indirect strategies that used to help learners control their emotions, attitudes, motivations, and values.

6) Social Strategy-One of indirect strategies that used to help learners learn language from other people.

\subsection{Anxiety about Foreign Language Learning}

According to MacIntyre, "Language learning is a cognitive activity that relies on encoding, storage, and retrieval processes, and anxiety can interfere with each of these..." (1995, p.96) [29]. The popularity of the study of anxiety can date back to Scovel's review the sparse literature concerning anxiety's role in language learning in 1978, and Horwitz, Horwitz, and Cope's [5] creating the Foreign Language Classroom Anxiety Scale (FLCAS) in 1986. It is believed that the effect of anxiety on language learning is two-folds: positive and negative. Horwitz' et al. divided the 33-item FLCAS into three categories: communication apprehension, test anxiety, and fear of negative evaluation, the three general sources of anxiety (Horwitz, et al., 1986) [5]. Hence, the possible sources and factors affecting students' language learning anxiety have been attracting much interest since the mid-1970s. Some studies dealing with anxiety's positive effects on foreign language learning indicated that anxiety might enforce students who have higher self-esteem and strong motivation to develop more positive attitude, favorable motivational intensity, use more appropriate strategies, arouse their potential, and achieve better outcome (Hou, 2013) [30], others included that anxiety may influence students' self-confidence, language learning behaviors, such as motivation, attitude, strategy use ( $\mathrm{Wu}, 2010)$ [31], and language learning achievement (Hou, et al, 2012) [32]. Particularly, Hou (2013) [30] pointed out that "there have been a growing number of studies of Asian learners of Japan, China, Taiwan, Korea, Vietnam, the Philippines, and many others" (p.58). Nevertheless, it seems that studies on Chinese learners who learn English as a foreign language were the dominant in this area of study. On the other hand, due to the growing economic and political influences of China in the world, more and more people are interested in learning Chinese as a foreign language than ever before. Under the greatly different system of Chinese character from that of other languages, it is no doubt that learning Chinese has become a great anxiety-provoking experience for many foreign language learners.

\section{Methodology}

Methodology included 1) research design, 2) subjects of the study, 3) research instruments, and 4) procedure. They were described below: 


\subsection{Research Design}

A case study and convenience sampling were used for the research methodology because the focus of attention is the case, not the whole population of cases. In addition, a case study has the advantages of combining qualitative and quantitative data in a complementary way (Stake 1988) [33], and in providing a depth study of a special case as well. "Some case studies are highly impersonal and statistical" (Stake 1988, 256) [33]. It is the study of a bounded system, which is in a particular circumstance and with a particular problem, and also gives readers "space" for their own opinions. Furthermore, the subjects included in the sample were "whoever happens to be available at that time" (Gay and Airasian, 2003, p.112) [34]. For example, in the study, the fourth graders of the Hospitality Management majors were excluded because they were not available at that time due to their doing out-off campus internship for one year.

\subsection{Subjects of the Study}

Subjects were 260 Hospitality Management major students in a private junior college in North-Eastern Taiwan, including 114 males and 146 females. Among them, they were the whole population of the first three grades and part of the fifth graders who were retaking the English course for some reasons. In total, 79 were first graders, 80 , second graders, 80 , third graders, and the rest 21 , fifth graders. When the study was conducted, the fourth year graders were absent from joining the research because they were doing their off-campus internship mainly in restaurants for one year. Furthermore, like many other schools, for conducting English homogeneous grouping instruction, every year, the students were divided into two classes of Regular level and Advanced level, based on their English scores of Junior College Entrance Exam. Based on students' self-reported information, $29.9 \%$ of the fathers had junior high school (or below) education, $49.8 \%$ had senior high school education, and the rest $20.3 \%$ had college (or above) education; while $27.7 \%$ of the mothers had junior high school (or below) education, 59.8\% had senior high school education, and the rest $12.5 \%$ had college (or above) education. As for parents' occupations, more than half of the fathers (53.9\%) worked in the field of industry/business, $14.0 \%$ worked as public servicers, and the rest $32.1 \%$ did other stuff, while $38.4 \%$ of the mothers worked in the field of industry/business, $8.1 \%$ worked as public servicers, and more than half did other stuff (53.5\%). In addition, only $36.2 \%$ of the students had the chance to go abroad for cross-cultural exchange experience, while the rest $63.8 \%$ didn't.

\subsection{Research Instruments}

In addition to 8 items dealing with students' background information (including gender, grade, parents' education and occupation, English levels, and going abroad experience), the rest 218 items of the research instruments of the study included Multiple Intelligences (MI) (Gardner, 1983) (90 items) [1], Attitude/ Motivation Test Battery (AMTB) (Gardner \& Lambert, 1972) (45 items) [18], 
Strategy Inventory for Language Learning (SILL) (Oxford, 1990) (50 items) [4], and Foreign Language Classroom Anxiety Scale (FLCAS) (Horwitz, Horwitz, \& Cope, 1986) (33 items) [5]. Except for Motivational Intensity, the part three of AMTB (Motivation), with 3 choices, all other scales were in Likert-scale format with a five responses of Strongly Agree $(\mathrm{SA}=5)$, Agree $(\mathrm{A}=4)$, No Comment $(\mathrm{NC}=3)$, Disagree $(\mathrm{D}=2)$, and Strongly Disagree $(\mathrm{SD}=1)$. Furthermore, in 9 items out of the 33 anxiety items of FLCAS, which statements were negatively worded, for example, item 2 "In English class, I don't worry about making mistakes", responses were reversed and recorded. In addition, the participants' English levels were used as their English proficiency. The students were divided into two classes of advanced level and regular level, based on their English scores of Junior College Entrance Exam. As for the questionnaires of the study, the Chinese versions of the questionnaire were adopted, partly with the intention of avoiding some students' possible misunderstanding of the item contents because of language proficiency limitation, and partly "if we have a group of students who all speak the same first language, we can use a translated form of an instrument-noting" (Liu, 2015, p.1875) [35]. The reliability of Multiple Intelligences (MI) (Gardner, 1983), Attitude/Motivation Test Battery (AMTB) (Gardner, 1985) [1], Strategy Inventory for Language Learning (SILL) (Oxford, 1990) [4], and Foreign Language Classroom Anxiety Scale (FLCAS) (Horwitz, Horwitz, and Cope, 1986) [5] was Cronbach's Alpha $0.984(n=90), 0.946(n=45)$, $0.984(n=50)$ and $0.899(n=33)$, respectively, with a Cronbach's Alpha $0.984(n$ $=218$ ) for the whole questionnaires. "If a test were perfectly reliable, the reliability coefficient would be 1.00. However, no test is perfect reliable" (Gay and Airasian, 2003, p.141) [34]. Hence, the results of the Cronbach's Alpha internal consistency reliability between $0.899-0.984$ indicated that the research instruments of the study were quite reliable. The details of the instruments of the study were displayed in Table 1.

\subsection{Procedure}

The study was conducted to revisit MI with the roles of motivation, strategy,

Table 1. Instruments of the study.

\begin{tabular}{lcccc}
\hline \multicolumn{1}{c}{ Scales } & Author & Year & $\begin{array}{c}\text { Item } \\
\text { number }\end{array}$ & $\begin{array}{c}\text { Alpha } \\
\text { Value }\end{array}$ \\
\hline $\begin{array}{l}\text { 1) Personal background } \\
\text { 2) Miltiple Intelligences (MI) }\end{array}$ & Self-created & 2015 & \\
$\begin{array}{l}\text { 3) Attitude/Motivation Test Battery } \\
\text { (AMTB) }\end{array}$ & Gardner, H. & 1983 & 90 & 0.984 \\
$\begin{array}{l}\text { 4) Strategy Inventory for Language } \\
\text { Learning (SILL) }\end{array}$ & Gardner, R.C.\& Lambert, W.E. & 1985 & 45 & 0.946 \\
$\begin{array}{l}\text { 5) Foreign Language Classroom } \\
\text { Anxiety Scales (FLCAS) }\end{array}$ & Oxford, R. & 1990 & 50 & 0.984 \\
\multicolumn{1}{c}{ Total } & Horwitz, Horwitz, \& Cope & 1986 & 33 & 0.899 \\
& & & & \\
\end{tabular}


and anxiety in foreign language learning. For carrying out English ability-grouping instruction, like many others in Taiwan, the school divided the students into two classes: advanced level class and regular level class, based on their English scores of entrance exam. To avoid possible misunderstanding for some students with limited English proficiency, and since all the subjects were Chinese, who spoke the same first language, hence, all items of the questionnaires were displayed in Chinese (Liu, 2015) [35]. Then, in the late 2016, a total of 271 Hospitality Management major students in the private five- year junior college were arranged to join in the study. If they agreed to participate in the study, they would sign their names on the answer sheet, if they hesitated, they didn't need to do that. Hence, discarding name-blank and incomplete ones, 260 answer sheets (96\%) were remained which were investigated in data analysis phrase. In other words, about $4 \%$ of the participants were excluded from the data analysis when investigating factors relating to students' English level. Along with descriptive statistics of mean and standard deviation, the data were analyzed by using The Statistical Package for the Social Science (SPSS, 14.0) to perform three other analyses. First, Pearson product-moment correlation was computed to find out the relationship among the subcategories of the questionnaires. Then, a Regression Analysis was used to determine what factors predictive to other variables and English level.

\section{Findings and Results}

Findings of the study included 1) descriptive analysis of students' MI, motivation, strategy, and anxiety; 2) Pearson correlation analysis of MI, motivation, strategy, anxiety, and English levels; 3) Regression analysis of predictive variables of English levels and other variables; as well as 4) summary of the findings. They were described below:

\subsection{Descriptive Analysis of MI, Motivation, Strategy, and Anxiety}

First, students were divided in two English classes, Advanced Level and Regular Level, based on their English scores of Junior College Entrance Exam. In the study there were 135 students in Advanced Class (51.9\%), while 125 students were in the Regular Class (48.2\%). They helped to fill out the questionnaires of the study. The mean scores were $\mathrm{M}=3.18$ ( $\mathrm{SD}=0.58$ ) for $\mathrm{MI} ; \mathrm{M}=3.03$ ( $\mathrm{SD}=$ 0.47 ) for motivation; $\mathrm{M}=3.03(\mathrm{SD}=0.64)$ for strategy, and $\mathrm{M}=3.09(\mathrm{SD}=0.41)$ for anxiety, respectively. Then, the findings revealed that the mean score of participants' overall MI was 3.16, with a standard deviation of 0.56 . They were stronger with those intelligences as Existential Intelligence $(M=3.33, S D=0.82)$ $\left(1^{\text {st }}\right)$, Visual/Spatial Intelligence $(\mathrm{M}=3.28, \mathrm{SD}=0.71)\left(2^{\text {nd }}\right)$, Intrapersonal Intelligence $(\mathrm{M}=3.25, \mathrm{SD}=0.75)\left(3^{\mathrm{rd}}\right)$, and Musical/Rhythmic Intelligence $(\mathrm{M}=$ $3.24, \mathrm{SD}=0.80)\left(4^{\text {th }}\right)$, and Bodily Intelligence $(\mathrm{M}=3.16, \mathrm{SD}=0.76)\left(5^{\mathrm{th}}\right)$. On the other hand, they were weaker with Interpersonal Intelligences $(\mathrm{M}=3.15, \mathrm{SD}=$ $0.72)\left(6^{\text {th }}\right)$, Verbal/Linguistic Intelligence $(M=3.12, S D=0.66)\left(7^{\text {th }}\right)$, Logical/ 
Mathematical Intelligence $(\mathrm{M}=3.08, \mathrm{SD}=0.71)\left(8^{\text {th }}\right)$, and Universal/Naturalist Intelligence $(\mathrm{M}=3.04, \mathrm{SD}=0.78)\left(9^{\mathrm{th}}\right)$. In particular, regarding to individual item of MI, the top six items with higher means were indicting "I like to have some background music when working or studying" (item 179$)(\mathrm{M}=3.55, \mathrm{SD}=$ 1.06), "I am easily touched by music" (item 182) $(\mathrm{M}=3.39, \mathrm{SD}=1.05)$ (both were Musical/Rhythmic Intelligence); and "I pay attention to the prettier or special things around me" (item 163$)(\mathrm{M}=3.38, \mathrm{SD}=0.87)(\mathrm{Visual} /$ Spatial Intelligence); as well as "I admire the beauty of nature, for example, sunset" (item 220) $(\mathrm{M}=3.38, \mathrm{SD}=0.98)$, "It is important to me to find my own mission in the world" (item 224) $(\mathrm{M}=3.38, \mathrm{SD}=0.97)$, "I believe that different kinds of meditation help us to know ourselves" (item 218) $(\mathrm{M}=3.36, \mathrm{SD}=0.94)$ (all the three were Existential Intelligence).

Second, the findings showed that students had fair overall motivation, including: orientations $(\mathrm{M}=3.38 / 5.00, \mathrm{SD}=0.63)$, attitude $(\mathrm{M}=3.28 / 5.00, \mathrm{SD}=$ $0.56)$ and motivational intensity $(M=1.99 / 3.00, S D=0.63)$ in learning English. Especially, they were motivated to learn English more instrumentally (oddnumber) $(\mathrm{M}=3.46 / 5.00, \mathrm{SD}=0.61)$ than integratively (even-number) $(\mathrm{M}=$ $3.31 / 5.00, \mathrm{SD}=0.68)(\mathrm{p}<0.01)$. The top five reasons for students to learn English were "To get a better job" (item 11) ( $\mathrm{M}=3.70, \mathrm{SD}=0.82)$, "To fulfill a school requirement" (item 9) $(\mathrm{M}=3.64, \mathrm{SD}=0.89)$, "To travel abroad" (item 21) $(\mathrm{M}=3.62, \mathrm{SD}=0.92)$, "English seems of great importance today" (item 23) $(\mathrm{M}=3.60, \mathrm{SD}=0.92)$, and "To make friends with foreign language speakers" (item 12) $(\mathrm{M}=3.52, \mathrm{SD}=0.88)$. Students had positive attitude toward English learning, mainly because of its importance (item 25$)(\mathrm{M}=3.61, \mathrm{SD}=0.90)$ and its being an international language (item 26$)(\mathrm{M}=3.61, \mathrm{SD}=0.91)$, so they wish they could speak English fluently (item 29$)(\mathrm{M}=3.57, \mathrm{SD}=0.92)$ and wanted to learn an additional foreign language in addition to English (item 35) $(\mathrm{M}=3.39$, $\mathrm{SD}=0.93$ ). Furthermore, $32.1 \%$ of the students either agree or strongly agree that they "hope to travel to an English speaking country (item 39), 37.6\% "hope to study abroad" (item 36), and even $32.5 \%$ "expect to have teachers who are native speakers of English" (item 41). As for motivational intensity, when they had a problem understanding something in English class, only $34.7 \%$ would "immediately ask the teacher for help" (item 45), and 56.1\% confessed that considering how they study English, they could honestly say that they "do just enough work to get along" (item 46), and 58.7\% reported that if teachers wanted someone to do an extra English assignment, they would only do it if the teacher asked them directly (item 50 ), while only $14.4 \%$ answered "definitely volunteer".

Third, the most frequently used strategy was Memory strategy (items 1 - 9) $(\mathrm{M}=3.11, \mathrm{SD}=0.65)\left(1^{\text {st }}\right)$, followed by Compensation strategy (items $\left.24-29\right)$ $(\mathrm{M}=3.06, \mathrm{SD}=0.69)\left(2^{\text {nd }}\right)$, and Social strategy (items $\left.45-50\right)(\mathrm{M}=3.04, \mathrm{SD}=$ $0.74)\left(3^{\text {rd }}\right)$. The least used strategy was Cognitive strategy (items $\left.10-23\right)(\mathrm{M}=$ $2.97, \mathrm{SD}=0.70)\left(6^{\text {th }}\right)$, then Affective strategy (items $\left.39-44\right)(\mathrm{M}=3.00, \mathrm{SD}=$ $0.72)\left(5^{\text {th }}\right)$, and Metacognitive strategy (items $\left.30-38\right)(\mathrm{M}=3.03, \mathrm{SD}=0.72)\left(4^{\text {th }}\right)$. Individual strategies that students used most were "When learning a new word, I 
create associates between new material and what I already know" (item 87) $(\mathrm{M}=$ $3.24, \mathrm{SD}=0.83)$, "I remember a new English word by making a mental picture of a situation in which the word might be used" (item 90) $(\mathrm{M}=3.24, \mathrm{SD}=0.84)$, and "I connect the sound of new English word and an image or picture of the word to help me remember the word" (item 89$)(\mathrm{M}=3.23, \mathrm{SD}=0.84)$. On the contrary, what individual strategies that students used least were "I write notes, messages, letters, or reports in English" (item 103) $(\mathrm{M}=2.87), \mathrm{SD}=0.86)$, "I memorize new English words by grouping them into categories (e.g., synonym, antonym; noun, verb)" (item 93) $(\mathrm{M}=2.91, \mathrm{SD}=0.78)$, and "I plan my schedule so I will have enough time to study English" (item 120$)(\mathrm{M}=2.92, \mathrm{SD}=0.85)$.

Fourth, Among the three kinds of anxiety, what students suffered most was Fear of Negative Evaluation (anxiety items 2, 7, 13, 19, 23, 31, 33) $(\mathrm{M}=3.13$, SD $=0.54)\left(1^{\text {st }}\right)$, then Communication Apprehension (anxiety items 1, 4, 9, 14, 15, $18,24,27,29,30,32)(\mathrm{M}=3.12, \mathrm{SD}=0.43)\left(2^{\text {nd }}\right)$, and Test Anxiety (anxiety items $3,5,6,8,10,11,12,16,17,20,21,22,25,26,28)(\mathrm{M}=3.05, \mathrm{SD}=0.40)$ $\left(3^{\text {rd }}\right)$. Students were more anxious to "keep thinking that other students are better at English than I am" (item 7) $(M=3.38, \mathrm{SD}=91)$, "feel overwhelmed by the number of rules to learn to speak English" (item 30) $(\mathrm{M}=3.30, \mathrm{SD}=86)$, "know that I am going to be called on in English class" (item 3$)(\mathrm{M}=3.29, \mathrm{SD}=0.91)$," find myself thinking about things that have nothing to do with the course" (item 6) $(\mathrm{M}=3.26, \mathrm{SD}=0.86)$, and " always feel that the other students speak English better than I do" (item 23$)(\mathrm{M}=3.26, \mathrm{SD}=0.86)$. The analysis was presented in Table 2 .

\subsection{Correlation Analysis among MI, Motivation, Strategy, Anxiety and English Level}

By Pearson correlation analysis, it was found that MI was correlated with motivation, strategy $(\mathrm{p}<0.01)$ and anxiety $(\mathrm{p}<0.01)$, but not English level; while motivation was correlated with MI $(\mathrm{p}<0.01)$, strategy $(\mathrm{p}<0.01)$, and English level ( $\mathrm{p}<0.05)$, but not anxiety. In addition, strategy was found to be correlated with MI $(\mathrm{p}<0.01)$ and motivation $(\mathrm{p}<0.01)$, but not anxiety and English level.

Table 2. Descriptive analysis of MI, motivation, strategy, anxiety, and English level.

\begin{tabular}{cccccc}
\hline questionnaire & $\mathrm{N}$ & Min & Max & M SD \\
\hline Multiple intelligences (MI) & 269 & 1.00 & 5.00 & 3.18 & 0.58 \\
Attitude/Motivation Test Battery (AMTB) (Motivation) & 271 & 1.00 & $5.00 / 3.00$ & 3.03 & 0.47 \\
Strategy Inventory for Language Learning (SILL) (Strategy) & 271 & 1.00 & 5.00 & 3.03 & 0.64 \\
Foreign Language Classroom Anxiety Scales (FLCAS) (Anxiety) & 271 & 1.00 & 5.00 & 3.09 & 0.41 \\
English level & 260 & 1.00 & 2.00 & & \\
Missing** & 11 & & & &
\end{tabular}

*Except for the third part of Attitude/Motivation Test Battery (AMTB), that is, Motivational intensity, there were only three responses, while the rest of the questionnaires were 5 responses. ${ }^{*}$ Missing indicated that those questionnaire answer sheets were no sufficient information. 
First, the findings revealed that all the subcategories of multiple intelligences were strongly correlated to one another $(\mathrm{p}<0.01)$.

Second, the findings revealed that all the subcategories of motivation: instrumental orientation, integrative orientation, attitude, and motivational intensity were strongly correlated to one another $(\mathrm{p}<0.01)$. In addition, English level was correlated with instrumental orientation $(\mathrm{p}<0.05)$ and motivational intensity $(\mathrm{p}$ $<0.05$ ), too.

Third, findings showed that all the six kinds of strategy were strongly correlated to one another $(\mathrm{p}<0.01)$.

Fourth, the findings showed that all the three kinds of anxiety, Comprehension Apprehension, Test anxiety, and Fear of Negative Evaluation were strongly correlated to one another $(\mathrm{p}<0.01)$.

Fifth, it was found that correlation among MI, motivation, strategy, anxiety, and English level did exist in one way or another. Findings showed that motivation and strategy were correlated with each other $(\mathrm{p}<0.01)$. But anxiety was only correlated with MI ( $p<0.01)$, while English level was only correlated with motivation $(\mathrm{p}<0.05)$. Additionally, all the nine types of multiple intelligences, four subcategories of motivation (instrumental orientation, integrative orientation, attitude, and motivational intensity); the six kinds of strategy; and the three types of anxiety were all correlated to one another $(\mathrm{p}<0.01)$, respectively. Furthermore, English level was correlated with Instrumental Orientation $(\mathrm{p}<0.05)$ and Motivational Intensity $(\mathrm{p}<0.05)$. The findings were displayed in Table 3.

Table 3. Correlation among MI, motivation, strategy, anxiety, and English level.

\begin{tabular}{|c|c|c|c|c|c|c|}
\hline & & MI & motivation & strategy & anxiety & English \\
\hline \multirow[t]{3}{*}{ MI } & Pearson correlation & 1 & $\left.0.430{ }^{* *}\right)$ & $\left.0.580{ }^{* *}\right)$ & $0.158\left(^{* *}\right)$ & 0.014 \\
\hline & Sig (two-tailed) & & 0.000 & 0.000 & 0.009 & 0.817 \\
\hline & $\mathrm{N}$ & 269 & 269 & 269 & 269 & 269 \\
\hline \multirow[t]{3}{*}{ motivation } & Pearson correlation & $0.430\left(^{* *}\right)$ & 1 & $0.550\left(^{* *}\right)$ & -0.080 & $0.122\left(^{*}\right)$ \\
\hline & Sig (two-tailed) & 0.000 & & 0.000 & 0.188 & 0.045 \\
\hline & $\mathrm{N}$ & 269 & 271 & 271 & 271 & 271 \\
\hline \multirow[t]{3}{*}{ strategy } & Pearson correlation & $0.580(* *)$ & $0.550(* *)$ & 1 & -0.086 & 0.018 \\
\hline & Sig (two-tailed) & 0.000 & 0.000 & & 0.157 & 0.768 \\
\hline & $\mathrm{N}$ & 269 & 271 & 271 & 271 & 271 \\
\hline \multirow[t]{3}{*}{ anxiety } & Pearson correlation & $0.158\left(^{* *}\right)$ & -0.080 & -0.086 & 1 & 0.053 \\
\hline & Sig (two-tailed) & 0.009 & 0.188 & 0.157 & & 0.384 \\
\hline & $\mathrm{N}$ & 269 & 271 & 271 & 271 & 271 \\
\hline \multirow[t]{3}{*}{ English } & Pearson correlation & 0.014 & $0.122\left(^{*}\right)$ & 0.018 & 0.053 & 1 \\
\hline & Sig (two-tailed) & 0.817 & 0.045 & 0.768 & 0.384 & \\
\hline & $\mathrm{N}$ & 269 & 271 & 271 & 271 & 271 \\
\hline
\end{tabular}

${ }^{* *} p<0.01 ;{ }^{*} p<0.05$ 


\subsection{Regression Analysis of MI, Motivation, Strategy, Anxiety Predictive to English Level}

Among the four variables of MI, motivation, strategy, and anxiety, only Motivation was found to be predictive to English level ( $\mathrm{p}<0.05)$. In other words, students with stronger motivation tended to have higher English level. The finding was displayed in Table 4.

Specifically, the following included the regression analysis of 1) MI predictive to motivation, strategy, anxiety, and English level; 2) motivation predictive to MI, strategy, anxiety, and English level; 3) strategy predictive to MI, motivation, strategy, anxiety, and English level; 4) anxiety predictive to MI, motivation, strategy, and English level; as well as 5) English level predictive to MI, motivation, strategy, and anxiety.

First, findings showed that among the 9 types of MI, factors predictive to Motivation was Intrapersonal intelligence $(\mathrm{p}<0.05)$, while factors predictive to strategy were Logical/Mathematical intelligence $(\mathrm{p}<0.01)$, Verbal/Linguistic intelligences $(\mathrm{p}<0.01)$, Visual/Spatial intelligences, negatively $(\mathrm{p}<0.01)$. As for factors predictive to anxiety were Verbal/Linguistic intelligences, negatively ( $\mathrm{p}<$ $0.05)$, Visual/Spatial intelligences $(\mathrm{p}<0.05)$, and Existential intelligence $(\mathrm{p}<$ 0.01), whereas factor predictive to English level was Existential intelligence, negatively $(\mathrm{p}<0.05)$. In other words, students with stronger Logical/Mathematical intelligence tended to use more strategies; while students with stronger Verbal/ Linguistic intelligence used more strategies and were less anxious; and students with stronger Visual/Spatial intelligence used less strategy and were more anxious. In addition, students with stronger Intrapersonal intelligence were more motivated, while students with stronger Existential intelligence were more anxious and had lower English level.

Second, motivation variables predictive to MI were Instrumental orientation $(\mathrm{p}<0.05)$ and Attitude $(\mathrm{p}<0.05)$, while variables predictive to strategy were attitude $(\mathrm{p}<0.01)$ and motivational intensity $(\mathrm{p}<0.01)$. As for variables predictive to anxiety was Motivational intensity, negatively $(\mathrm{p}<0.05)$, whereas variables predictive to English level were Instrumental orientation $(\mathrm{p}<0.05)$, Integrative orientation ( $\mathrm{p}<0.05)$, and Motivational intensity $(\mathrm{p}<0.05)$. In other words, students with stronger instrumental orientation were with stronger MI and higher

Table 4. Regression analysis of MI, motivation, strategy, anxiety predictive to English level.

\begin{tabular}{cccccc}
\hline Variables & $\mathrm{B}$ & $\mathrm{SEB}$ & $B$ & $\mathrm{t}$ & $\mathrm{Sig}$ \\
\hline 1 (Constant) & 1.596 & 0.354 & & 4.514 & 0.000 \\
Multiple Intelligence (MI) & -0.002 & 0.074 & -0.002 & -0.028 & 0.977 \\
Motivation & 0.177 & 0.087 & 0.152 & 2.037 & 0.043 \\
Strategy & 0.054 & 0.072 & 0.063 & 0.749 & 0.454 \\
Anxiety & -0.071 & 0.085 & -0.053 & -0.834 & -0.405 \\
\hline
\end{tabular}

Dependent variable: English level ${ }^{\star} p<0.05$. 
English level; while students with stronger integrative orientation were with higher English level, too. In addition, students with more positive attitude were with stronger MI and used more strategies, while students with stronger motivational intensity used more strategies, were less anxious, and had higher English level.

Third, among the six kinds of strategy, Memory strategy was predictive anxiety $(\mathrm{p}<0.01$ ), while Cognitive strategy was predictive to anxiety negatively $(\mathrm{p}<$ $0.01)$, and Metacognitive strategy was predictive to motivation $(\mathrm{p}<0.01)$. In addition, Affective strategy was predictive to both anxiety $(\mathrm{p}<0.01)$ and English level negatively $(\mathrm{p}<0.05)$, while Social strategy was predictive to anxiety negatively $(\mathrm{p}<0.05)$. That is to say, students using more Memory strategy were more anxious, while students using more Cognitive strategy were less anxious, and students using more Metacognitive strategy were with stronger motivation. In addition, students using more Affective strategy were more anxious and had lower English level), while students using more Social strategy were less anxious.

Fourth, among the three types of anxiety, Communication Apprehension was predictive to English level $(\mathrm{p}<0.05)$ (i.e. students with more anxiety of Communication Apprehension had lower English level), while Test Anxiety was predictive to all MI, motivation, strategy, and English level negatively $(\mathrm{p}<0.01)$ (i.e. students with higher Test anxiety had weaker MI and motivation, used less strategy, and had lower English level). In addition, Fear of Negative Evaluation was predictive to MI, motivation and strategy (all $\mathrm{p}<0.01$ ) (i.e. students with more Fear of Negative Evaluation had stronger MI and motivation, and used more strategies).

Fifth, the findings showed that English level was only predictive to motivation $(\mathrm{p}<0.05)$ (i.e. students with higher English level had stronger motivation).

\subsection{Summary of the Findings}

Summary of the findings included were described below:

\subsubsection{Descriptive Analysis of MI, Motivation, Strategy, Anxiety, and English Level}

For the whole research instrument of the study, it had a fair mean score between 3.03 and 3.18 , indicating that students had favorable intelligences, strong motivation, positive attitude, and fair level of anxiety toward English learning. First, students were stronger with Existential intelligence $\left(1^{\text {st }}\right)$, Visual/Spatial intelligence $\left(2^{\text {nd }}\right)$, Intrapersonal intelligence $\left(3^{\text {rd }}\right)$, Musical/Rhythmic intelligence $\left(4^{\text {th }}\right)$, Bodily intelligence $\left(5^{\text {th }}\right)$, followed by Interpersonal intelligence $\left(6^{\text {th }}\right)$, Verbal/ Linguistic intelligence $\left(7^{\text {th }}\right)$, Logical/Mathematic intelligence $\left(8^{\text {th }}\right)$, and Universal/ Naturalist intelligence $\left(9^{\text {th }}\right)$. Second, students had favorable orientations, attitude, and motivational intensity in learning English. Especially, they were motivated to learn English more instrumentally than integratively $(\mathrm{p}<0.01)$. Third, the most frequently used strategy was Memory strategy $\left(1^{\text {st }}\right)$, followed by Compensation strategy $\left(2^{\text {nd }}\right)$, Social strategy $\left(3^{\text {rd }}\right)$, Metacognitive strategy $\left(4^{\text {th }}\right)$, Affec- 
tive strategy $\left(5^{\text {th }}\right)$, and Cognitive strategy $\left(6^{\text {th }}\right)$. Last, among the three kinds of anxiety, what students suffered most was Fear of Negative Evaluation $\left(1^{\text {st }}\right)$, then Communication Apprehension $\left(2^{\text {nd }}\right)$, and Test Anxiety $\left(3^{\text {rd }}\right)$.

\subsubsection{Correlation Analysis among MI, Motivation, Strategy, Anxiety, and English Level}

The findings showed that motivation and strategy were correlated with each other $(\mathrm{p}<0.01)$. But anxiety was only correlated with MI $(\mathrm{p}<0.01)$, while English level was only correlated with motivation $(\mathrm{p}<0.05)$. Additionally, all the nine types of multiple intelligences, four subcategories of motivation (instrumental orientation, integrative orientation, attitude, and motivational intensity); the six kinds of strategy; and the three types of anxiety were all correlated to one another $(\mathrm{p}<0.01)$, respectively. Furthermore, English level was correlated with Instrumental Orientation $(\mathrm{p}<0.05)$ and Motivational Intensity.

\subsubsection{Regression Analysis of MI Predictive to Motivation, Strategy, Anxiety, and English Level}

It was found that, first, among the 9 types of MI, Logical/Mathematical intelligence was predictive to strategy $(\mathrm{p}<0.01)$ (i.e. students with stronger Logical/ Mathematical intelligence tended to use more strategies), while Verbal/Linguistic intelligence was predictive to strategy $(\mathrm{p}<0.01)$ anxiety, negatively $(\mathrm{p}<0.05)$ (i.e. students with stronger Verbal/Linguistic intelligence used more strategies and were less anxious); and Visual/Spatial intelligence was predictive to strategy, negatively $(\mathrm{p}<0.01)$ and anxiety $(\mathrm{p}<0.01)$ (i.e. students with stronger Visual/ Spatial intelligence used less strategies and were more anxious). In addition, Intrapersonal intelligence was predictive to motivation $(\mathrm{p}<0.05)$ (i.e. students with stronger Intrapersonal intelligence were more motivated), while Existential intelligence was predictive to both anxiety $(\mathrm{p}<0.01)$ and English level, negatively $(\mathrm{p}<0.05)$ (i.e. students with stronger Existential intelligence were more anxious and had lower English level). Second, among the subcategories of motivation, instrumental orientation was be predictive to both MI $(\mathrm{p}<0.05)$ and English level $(\mathrm{p}<0.05)$ (i.e. students with stronger instrumental orientation were with stronger MI and higher English level); while integrative orientation was predictive to English level (i.e. students with stronger integrative orientation were with higher English level) $(\mathrm{p}<0.05)$, too. In addition, attitude was predictive to both MI $(\mathrm{p}<0.05)$ and strategy $(\mathrm{p}<0.01)$ (i.e. students with more positive attitude were with stronger MI and used more strategies), while motivational intensity was predictive to strategy $(\mathrm{p}<0.01)$, anxiety negatively $(\mathrm{p}<0.05)$ and English level $(\mathrm{p}<0.05)$ (i.e. students with stronger motivational intensity used more strategies, were less anxious, and had higher English level). Third, among the six kinds of strategy, Memory strategy was predictive anxiety $(\mathrm{p}<$ 0.01) (i.e. students using more Memory strategy were more anxious), while Cognitive strategy was predictive to anxiety negatively $(\mathrm{p}<0.01)$ (i.e. students using more Cognitive strategy were less anxious), and Metacognitive strategy was predictive to motivation $(\mathrm{p}<0.01)$ (i.e. students using more Metacognitive strategy 
were with stronger motivation). In addition, Affective strategy was predictive to both anxiety $(\mathrm{p}<0.01)$ and English level negatively $(\mathrm{p}<0.05)$ (i.e. students using more Affective strategy were more anxious and had lower English level), while Social strategy was predictive to anxiety negatively $(\mathrm{p}<0.05)$ (i.e. students using more Social strategy were less anxious). Fourth, among the three types of anxiety, Communication Apprehension was predictive to English level negatively ( $\mathrm{p}<$ 0.05) (i.e. students with more anxiety of Communication Apprehension had lower English level), while Test Anxiety was predictive to all MI, motivation, strategy, and English level negatively $(\mathrm{p}<0.01)$ (i.e. students with higher Test anxiety had weaker MI and motivation, used less strategy, and had lower English level). In addition, Fear of Negative Evaluation was predictive to MI, motivation and strategy (all p < 0.01) (i.e. students with more Fear of Negative Evaluation had stronger MI and motivation, and used more strategies). Last, as for English level, it was only predictive to motivation $(\mathrm{p}<0.05)$ (i.e. students with higher English level had stronger motivation), but not MI, strategy and anxiety.

\section{Conclusions, Implication and Limitation}

\subsection{Conclusions of the Study}

Findings of the study provided answers to the main research question of how multiple intelligence (MI) related to motivation, strategy, and anxiety in English learning. The conclusions covered the followings:

The findings revealed that students were stronger with those intelligences as Existential Intelligence $\left(1^{\text {st }}\right)$, Visual/Spatial Intelligence $\left(2^{\text {nd }}\right)$, Intrapersonal Intelligence $\left(3^{\text {rd }}\right)$, Musical/Rhythmic Intelligence $\left(4^{\text {th }}\right)$, and Bodily Intelligence $\left(5^{\text {th }}\right)$. On the other hand, they were weaker with Interpersonal Intelligences $\left(6^{\text {th }}\right)$, Verbal/Linguistic Intelligence $\left(7^{\text {th }}\right)$, Logical/Mathematical Intelligence $\left(8^{\text {th }}\right)$, and Universal/ Naturalist Intelligence $\left(9^{\text {th }}\right)$. The findings were quite similar to that of other two studies in Taiwan conducted by Hou \& Cheng (2014) [17], showing that Existential Intelligence was those Taiwanese students' strongest intelligence, but Musical intelligence ranked the fourth $\left(4^{\text {th }}\right)$ in the present study, while it ranked the second $\left(2^{\text {nd }}\right)$ in the other two studies while the weaker ones were Logical/Mathematical Intelligence $\left(8^{\text {th }}\right)$, and Universal/Naturalist Intelligence $\left(9^{\text {th }}\right)$. The possible explanation might be the difference of students' ages. The participants in the present study were junior college students with the mean age of 17 (range 15 - 19 years), while subjects of the other two were college students with the mean age of 19.5 (range 18 - 21 years). It seems that younger students tend to have stronger Musical intelligence, which was consistent with the finding of Hou's (2013) [30], while Musical intelligence ranked the first $\left(1^{\text {st }}\right)$ for those 107 high school students with the mean age of 16 (range 15 - 17 years).

In the study, students had strong motivation to learn English, especially they were motivated more instrumentally than integratively, which was quite the same as that of many other studies of investigating foreign language learning (FLL) [6] [20] [23] [36]. In addition, the study found that integrative orientation 
was also predictive to English level, which was consistent with other findings indicating that both integrative orientation and instrumental orientation have positive influences on second or foreign language learning [3] [19]. As for Strategy, it was not surprising to find that students, like many Asian students, used Memory strategy most [31]. Whereas the strong correlation among motivation, strategy, anxiety, and English level was supported that the more motivated students, the more positive attitude they have, the more time and effort they are willing to spend, the more strategies they use, the less anxious they are, and better language performance they achieve [3] [4] [5] [28].

\subsection{Implications and Suggestions for Students, Teachers, Parents, and Schools}

Some implications and suggestions for students, teachers, parents and schools were described below:

First, for students: The results of the study could be used to help students be familiar with their multiple intelligences, learning behaviors, and the possible impacts on their English learning. Also, the findings could be used to convince students to become interested in developing more favorable attitude and motivational intensity. By so doing, students can, in general, make the best use of their intelligence strengths, develop stronger motivation, use more language learning strategies, and become less anxious in foreign language learning.

Second, for teachers: As for teachers, it is hoped that teachers can play the role as a "language coach", to provide all students equal opportunities to appreciate their strengths and improve their weakness to learn. In addition, teachers should act as active agents in the learning process to help students not only to awaken, amplify, learn, and transfer the intelligences [13] but also to raise their selfawareness that language learning is a complex process and influenced by many factors, and some are "predispositions" [8], which can be developed, cultivated, trained, and taught [4] [9] [37], and strong motivation can go a long way during the process. More importantly, success breeds success, so it is suggested that teachers be aware of the importance of helping students build up self-confidence and sense of accomplishment by providing appropriate feedback [24] [25].

Last, for parents and schools: Last but not least, based on the study, about one third of the students expressed the intention "to travel to an English speaking country". However, only $36.2 \%$ of them self-reported that they had been going abroad for cross-cultural exchange experience (CCEE). In other words, almost nearly two-thirds of the students didn't the chance to experience the cross-cultural exchange. Consequently, on one hand, those students who were without the chance to go abroad for cross-cultural experience should be encouraged to keep studying harder to strengthen their motivational intensity to reach a significant level for using more strategies, having more self-confidence, being less anxious, and reaching higher English level. On the other hand, if possible, parents should support and encourage their children to experience the cross-cultural exchange. 
At the same time, schools should try to provide students the environment with more chances to develop cross-cultural awareness and represent their most immediate meaningful contact with the target language itself.

\subsection{Limitations of the Study}

There were three limitations of the study. First, the participants excluded the fourth graders of the department due to their doing off-campus internship, hence, the findings might not be representative of the whole population of the department majors. Second, the students' English levels were adopted from their English scores of junior college entrance exam, and were only divided into two levels of Regular and Advanced, hence, it might not be strong enough to support the findings; therefore, to provide an appropriate English test is quite necessary in the future studies. Third, the questionnaire investigation had nothing to do with students' academic performance, so they might not be serious enough to complete the questionnaire; therefore, some kinds of feedback (such as appropriate gifts or bonus) should be prepared in the future studies. All the limitations above might influence the result to some extent.

\section{References}

[1] Howard, G. (1983) Frames of Mind: The Theory of Multiple Intelligences. Basic Books, New York.

[2] McKenzie, W. (2004) Multiple Intelligences and Instructional Technology. http://surfaquarium.com

[3] Robert, G. (1985) Social Psychology and Second Language Learning: The Role of Attitude and Motivation. Edward Arnold, Baltimore.

[4] Oxford, R. (1990) Language learning Strategies: What Every Teacher Should Know. Newbury House/Harper \& Tow, New York.

[5] Horwitz, E., Michael, H. and Joann, C. (1986) Foreign Language Classroom Anxiety. The Modern Language Journal, 70, 125-132. https://doi.org/10.1111/j.1540-4781.1986.tb05256.x

[6] Dornyei, Z. (1994) Motivation and Motivating in the Foreign Language Classroom. The Modern Language Journal, 78, 273-284. https://doi.org/10.1111/j.1540-4781.1994.tb02042.x

[7] Shayeghi, R. and Hosseinioun, P. (2015) The Relationship between Iranian EFL Learners' Multiple Intelligences and Their Performance on Grammar Tests. International Scholarly and Science Research \& Innovation, 9, 2972-2976.

[8] Jamieson, J. (1992) The Cognitive Styles of Reflection/Impulsivity and Fields Independence/Dependence and ESL Success. The Modern Language Journal, 76, 491-501. https://doi.org/10.1111/j.1540-4781.1992.tb05398.x

[9] Titone, R. (1990) A Psycho-Sociolinguistic Perspective in EFL Learning: The Role of Attitude a Dynamic Factor. Rassegna Italiana di Linguistica Applicata, 23, 5-17.

[10] Gardner, H. (1993) Multiple Intelligences: The Theory in Practice. Basic Books, New York.

[11] Gardner, H. (2003) Multiple Intelligences after Twenty Years. Paper Presented at the American Educational Research Association, Chicago, April 21, 2003.

[12] Ely, C.M. and Pease-Alvarez, C. (1996) Learning Styles and Strategies in ESOL: In- 
troduction to the Special Issue. TESOL Journal, 6, 5.

[13] Christison, M.A. (1998) An Introduction to Multiple Intention Theory and Second Language Learning. In: Reid, J., Ed., Understanding Learning Styles in the Second Language Classroom, 1-14.

[14] Hou, Y. (2016) The Impacts of Multiple Intelligences on Tolerance of Ambiguity and English Proficiency-A Case Study of Taiwanese EFL College Students. Open Journal of Modern Linguistics, 6, 255-275. https://doi.org/10.4236/ojml.2016.64028

[15] Kim, I.S. (2009) The Relevance of Multiple Intelligences to CALL Instruction. The Reading Matrix, 9, 1-21.

[16] Saeidi, M. and Karvandi, F. (2014) The Relationship between EFL Learners' Multiple Intelligences and Their Performance on Reason-Gap Writing Tsk. International Journal of Language Learning and Applied Linguistics World, 5, 189-202.

[17] Hou, Y. and Cheng, H.Y. (2014) The Nine Intelligences and Six Learning Styles in College Students' Academic Performance-A Case Study. Journal of National United University, 11, 35-62.

[18] Gardner, R. and Lambert, W. (1959) Motivational Variables in Second Language Acquisition. Canadian Journal of Psychology, 13, 266-272. https://doi.org/10.1037/h0083787

[19] Horwitz, E. (1990) The Beliefs about Language Learning of Beginning University Students. The Modern Language Journal, 72, 182-193.

[20] Kissau, S. (2006) Gender Differences in Second Language Motivation: An Investigation of Micro- and Macro-Level Influences. Canadian Journal of Applied Linguistics, 9, 73-96.

[21] Oxford, R. (2003) Language Learning Styles and Strategies: An Overview. GALA, 1-25.

[22] Oxford, R. and Nyikos, M. (1989) Variables Affecting Choice of Language Learning Strategies by University Students. Modern Language Journal, 73, 291-300. https://doi.org/10.1111/j.1540-4781.1989.tb06367.x

[23] Whartorn, G. (2000) Language Learning Strategy Use of Bilingual Foreign Language Learners in Singapore. Language Learning, 50, 203-243. https://doi.org/10.1111/0023-8333.00117

[24] Gardner, R. and Lysynchuk, L. (1990) The Role of Aptitude, Attitude, Motivation, and Language Use on Second-Language Acquisition and Retention. Canadian Journal of Behavioral Science, 22, 254-270. https://doi.org/10.1037/h0078924

[25] Kraemer, R. and Olshtain, E. (1989) Perceived Ethnolinguistic Vitality and Language Attitudes: The Israeli Setting. Journal of Multilingual and Multicultural Development, 10, 197-212. https://doi.org/10.1080/01434632.1989.9994374

[26] Oxford, R. and Cohen, A.D. (1992) Language Learning Strategies: Crucial Issues of Concepts and Classification. Applied Language Learning, 3, 1-35.

[27] Yu, S.L. and Elde, A.D. (1995) Motivation and Cognitive Strategies in Students with a "Good Student" or "Poor Student" Self-Schema. Poster Presented at the AERA, San Francisco, 18-22 April.

[28] Young, D.J. (1995) Raising General Awareness of Language Learning Strategies: A Little Bit Goes a Long Way. Hispania, 78, 337-358.

[29] MacIntyre, P.D. (1995) How Does Anxiety Affect Second Language Learning? A Reply to Sparks and Ganschow. The Modern Language Journal, 79, 90-99. https://doi.org/10.1111/j.1540-4781.1995.tb05418.x

[30] Hou, Y. (2013) Taiwanese College Students' Anxiety about Foreign Language 
Learning between English Majors and Non-English Majors. WHAMPOA-An Interdisciplinary Journal, 65, 57-80.

[31] Wu, K.H. (2010) The Relationship between Language Learners' Anxiety and Learning Strategy in the CLT Classroom. International Education Studies, 3, 174-191.

[32] Hou, Y., Lee, F.-M., Hou, Y.-A., Chung, W.-Y. and Cheng, H.-Y. (2012) The Impacts of Teachers' Beliefs on Students' Anxiety about Foreign Language Learning: The East and the West. The International Journal of the Humanities, 9, 245-260. https://doi.org/10.18848/1447-9508/CGP/v09i08/43302

[33] Stake, R.E. (1988) Case study Methods in Educational Research: Seeking Sweet Water. In: Jaeger, R.M., Ed., Complementary Methods for Research in Education, American Educational Research Association, Washington DC, 253-300.

[34] Gay, L. and Airasian, P. (2003) Educational Research: Competencies for Analysis and Applications. 7th Edition, Merrill Prentice Hall.

[35] Liu, C. (2015) Relevant Researches on Tolerance of Ambiguity. Theory and Practice in Language Studies, 5, 1874-1882. https://doi.org/10.17507/tpls.0509.15

[36] Cheng, H.-Y., Lee, F.-M., Liou, P.-P. and Chung, W.-Y. (2010) Are Females Better Language Learners? WHAMPOA-An Interdisciplinary Journal, 59, 55-72.

[37] Bialystok, E. and Frohlich, M. (1978) Variables of Classroom Achievement in Second Language Learning. Modern Language Journal, 62, 327-336.

Open Access Library

Submit or recommend next manuscript to OALib Journal and we will provide best service for you:

- Publication frequency: Monthly

- 9 subject areas of science, technology and medicine

- Fair and rigorous peer-review system

- Fast publication process

- Article promotion in various social networking sites (LinkedIn, Facebook, Twitter, etc.)

- Maximum dissemination of your research work

Submit Your Paper Online: Click Here to Submit

Or Contact service@oalib.com 